\title{
Prospects for the development of leasing relations in the agro-industrial sector
}

\author{
Svetlana Rybak $^{1}$ and Irina Krygina $^{1 *}$ \\ ${ }^{1}$ Don State Technical University, 1, Gagarin Sq., 344003, Rostov-on-Don, Russia
}

\begin{abstract}
The article is devoted to the conceptual analysis of the problems related with the development of contractual relations in the agricultural sector of the modern Russian economy, which has recently begun to show tendensis towards its intensive development. This fully applies to the development of contractual leasing relations as a way of making agricultural infrastructure more effective. The analysis of this direction in the field of legal regulation of leasing relations allowed us in this study to reveal and justify the scientific and theoretical concepts of the modern contractual process in agriculture and, accordingly, to determine the goals and objectives of the study. The aim of the work is to update the scientific and research interest in the problem of the development of leasing relations in the agricultural sector of the modern Russian economy. At the same time, the objectives of the study allowed the authors to specify the main directions of the state's financial policy in the agricultural sector of the economy.
\end{abstract}

\section{Introduction}

Entering into the process of reforming its economic system Russia is focused on approaching the world standards of economic management, while choosing the most effective areas of development. It is the financial lease (leasing) that currently represents a very reliable tool that allows economic entities to have legal protection against unscrupulous counterparties and economic instability. The financial lease agreement itself appeared in Russia at the end of the twentieth century or the period of formation of the market economy in Russia. In order of further developing the economy, it was simply necessary to study the legal model of financial leasing, because it had a huge potential and prospects for investment activity for the Russian Federation.One of the main problems was that an imperfect regulatory framework was created, which hindered the effective development and implementation of leasing [1]. That is why the problem of leasing legal relations is of genuine interest, both among theorists and practitioners.

\section{Materials and methods}

\footnotetext{
* Corresponding author: Kryginairina@yandex.ru
} 
Taking into account the problematic nature of the development of the agricultural sector of the modern Russian economy, and the interest that economic entities show in the prospects for its development, it is necessary to formulate the target setting of the problem under consideration within the framework of the study. The purpose of the study is to conduct a comprehensive study of leasing legal relations, to identify the place of the financial lease agreement (leasing) in civil legislation and law; to study the judicial practice of leasing legal relations to identify gaps in the current legislation. In this regard, to achieve the goal of the study, it is necessary to solve the following research tasks. They are primarily related to the scientific and theoretical understanding of the legal nature of leasing relations, their retrospective analysis of the conditions of their development in domestic law and legislation, as well as the law of foreign countries that are world producers of agricultural production. Another important task is to identify problems in the implementation of financial lease transactions (leasing) as an important tool for stimulating agricultural production. In addition, when studying this problem, it is impossible not to avoid the socalled "risk factors" that may arise when entities enter into leasing legal relations. Finally, it is impossible to ignore the problem of the exercise of real rights in leasing, the mechanisms of transfer of ownership from the owner of the object of leasing legal relations to its owner and user [2].

The scientific-theoretical basis of this study abstrahierte based on the object of study, which the authors define leasing legal relations regulated by civil legislation of the Russian Federation and the problems of application and improvement of the Russian legislation in the sphere of leasing relations [3].

The subject basis of the research is the civil legislation of the Russian Federation regulating leasing legal relations. The methodological science-intensive complex used by the authors in the study, which includes a combination of general scientific and private scientific tools, made it possible for the authors to present a systematic scientific analysis of the problem of the development of contractual relations in agricultural production on the basis of the introduction of leasing relations as the most effective way of material and financial support for agricultural producers in modern conditions [4].

\section{Results and discussion}

It would seem that the history of leasing should begin quite recently, because in Russia, for example, leasing appeared in general at the end of the 20th century, and the first Federal Law: "On Leasing"was put into effect on October 29, 1998. However, this is not the case. The very first mention of leasing dates back to about $2000 \mathrm{BC}$, in the oncestrongest state of ancient Sumer. In the present territory of the Sumerian city of Ur, clay tablets were found containing information about the lease of property at that time: agricultural equipment, livestock, land, water bodies, and the like. The landlords of that time were the priests, who concluded a contract with the farmers, under which the farmers took the lease of this very property with its subsequent purchase. It is these tablets that are one of the proofs that leasing originates quite from ancient times [5]. Other ancient civilizations: the Greeks, Egyptians, and Romans believed that renting was one of the easiest and most stable ways to purchase equipment. At that time, few people could afford the full purchase of the property, so it was the financial lease that helped with this. The lease was legally secured by the Roman Emperor Justinian [6]. Through the codification of Roman law, it reflected a Finance lease in the legal documents, gave her some kind of legal force. More recently, documents dating back to the 11th century were discovered in Venice, similar to the modern legal model of leasing. The documents contained information at the time that the Venetians-the rightholders of commercial anchors, rented them out, since at that time the anchors were 
very expensive. The tenants returned the anchors to their owners after the voyage. They, in turn, rented them out again, to other tenants. In essence, this is very similar to the current financial lease agreement.

In the 19th century, the era of railway development began, so in the leading countries of that time, in the United States and Great Britain, there was an application for leasing railway cars. In the same century, the TV company: "Bell " stopped selling its equipment, and began to rent it out. After all, the pragmatic minds of this company made an economic forecast and came to the conclusion that renting out their equipment would be much more profitable than just selling it. At the same time, in a well-known book of that time: "how to do business in Europe" by an equally well-known author, J. Van Horne, there was the very first mention of the term: "Leasing [7].

Later, at the beginning of the 20th century, cars began to appear on the market. Not all people could afford to buy a car immediately and now, so leasing saved their situation. So, for example, the founder of the company: "Ford" Henry Ford, for the sale of their cars began to use financial leasing (leasing.

In our country, leasing appeared during the Second World War. The Soviet Union in the early years of the war he could not produce a large amount of military equipment needed for the war with the enemy, and buy at full price from their "allies" in the face of US also haven't been able, so by leasing carried out the delivery of military equipment to the Soviet Union from the United States.

At the same time, the real economic "boom" occurred in the post-war period, in the mid-50s of the 20th century, when the USSR still purchased a huge amount of equipment from the United States through leasing relations. Equipment, machines, mechanisms, military equipment and so on began to be rented out in huge numbers. And yet, the founder of the modern leasing industry is the American Henry Schofeld, who founded a company dealing with leasing legal relations in the 50s. Until that moment, there was simply no company in the world that was fully engaged in the leasing industry [8]. Yes, before that, there were small, usually local companies, but their activities did not extend to the whole world, but only to the place where they existed. That is why leasing gradually became "international" thanks to the development of such huge companies as the Henry Schofeld company. In 1971, in the United States, the law allowed banks to approve subsidiaries so that they could lease equipment, and then real estate [9.] It was this event that further expanded the leasing business, more and more companies began to register in order to create a leasing business, after the monopoly there was real competition, ordinary people had the opportunity to choose, to look for more favorable offers on the market [10].

In Russia, leasing appeared more recently, around the $80 \mathrm{~s}$. There is a general opinion that up to this time, if leasing was used, it was on a small scale, and, as a rule, in international trade, but not in domestic trade. In Russia, the purpose of its use was the purchase of expensive equipment, machinery, cars, computer machines, ships, aircraft, tanks, and so on. That is, very expensive equipment and items that the USSR could not afford to buy immediately. A special form of leasing was used, which implied the conclusion of a loan and the formation of an agreement concluded between the USSR and any other country, a kind of lease for a certain period, followed by the purchase of these items. Separately, it is necessary to point out the leasing operations in which the USSR, through leasing, leased long-distance ships from other countries. The meaning was as follows: between the Ministry of the Sea Fleet of the USSR and any intermediary foreign firm, a contract was concluded, under which the foreign firm undertook to provide the USSR with a ship for rent without a crew. The ship was brought to any port in Western Europe, under the flag of a third country. On the ship, the Soviet Union sent its crew. After the arrival of the crew, the flag of the Soviet Union was raised on the 
ship and the ship was placed at the disposal of the country. The obligatory moment was that the USSR was obliged to buy out this vessel at the end of the lease term. In addition to ships, the Soviet Union thus "bought" cars, tractors, trailers, bodies. In total, during this time, a significant amount of equipment was purchased, which was previously in operation for 5 to 10 years. But still, leasing in international operations was used very rarely, because until 1989, the enterprises of the Soviet Union did not have foreign currency[11]. This meant that Soviet enterprises simply have not been possible to acquire foreign assets. Therefore, the beginning of leasing relations in the domestic market of the USSR is considered to be the time after 1989, when enterprises had the opportunity to receive foreign currency. Therefore, in the early $90 \mathrm{~s}$, leasing companies began to appear in Russia. In the mid-90s, leasing was actively considered by the legislative authorities, as it had a huge potential for the economic development of the country. The Federal Law "On Financial Lease (Leasing)" was adopted in 1998, which regulates the main legal issues related to leasing. The basis was laid. In the future, this Federal Law was supplemented, individual articles were changed. In addition to the Federal Law: "On financial lease (leasing)"other laws regulating the legal relations of leasing have been adopted. For example, the Civil Code in articles 665 to 670 fixed the concepts of the subject of the lease agreement, the responsibility of the seller, and much more. In 1994, 15 Russian companies created an association of leasing companies, called "Rosleasing". To date, about 90 companies are members of Rosleasing, which indicates the growing popularity of leasing.

The very fact of the existence of this scientific problem raises the most important question for researchers: what is the economic essence of leasing relations? After the transition to market relations in the $90 \mathrm{~s}$, entrepreneurs, private firms, and organizations began to appear en masse in Russia. Factories and huge enterprises were privatized, as a result of which leasing and various financial contracts became popular. After the collapse of the USSR, alas, there was an economic decline For Russia, and as a result there was an economic crisis. The country needed to raise production, to get out of this economic crisis. Therefore, our country began to adopt the experience of Western countries, where financial leasing was actively used, since it is very profitable for enterprises that took expensive property in this financial lease [12]. The financial recovery of the market began, enterprises could produce their products, saturating the domestic and foreign markets. The "leasing" category is very versatile and complex. Researchers interpret it from different points of view, but it is traditionally believed that leasing contains three aspects: financial and legal, commercial and technical [13]. Leasing is a long-term lease of machinery, equipment, vehicles, production facilities, etc., with the possibility of their subsequent purchase at the residual value. More precisely, the economic meaning of leasing reveals V. Gazman, who notes, " ... leasing is an entrepreneurial activity aimed at investing temporarily free or attracted financial volume in equipment and then leasing this equipment for financial lease. Based on the financial lease (leasing) agreement, the lessor (lessor) is obliged to acquire the property stipulated in the contract and provide this property to the lessee (lessee) on the terms of payment and temporary use"[14].

In its economic essence, leasing is very similar to credit relations, since leasing is the following: 1) it is concluded by two parties: the lessor and the lessee, although a third party is also involved in the leasing relationship: the seller of the property that the lessee wants to buy; 2) in leasing, unlike a loan, only property (movable and immovable) is taken, while only cash is taken on credit. Of course, at the same time, leasing cannot be considered a kind of any contract, since it is unique in its own way; it is completely independent, endowed with its own specific features. It should be noted that the legal definition of leasing describes it as consensual (that is, the contract is recognized as 
concluded from the moment it is signed by the parties), paid (assumes mutual benefit), mutual, bilateral ( 2 subjects of legal relations), conditional, casual and basic. Please note that such conditions are inherent in most civil contracts.

The Russian Federal Law "On Financial Lease (Leasing)" contains the main legal and economic features of leasing: The property that is the subject of leasing should not lose its physical properties in the process of use. The law contains the term that such property is "Not consumed". Examples of such property: enterprises, factories, machinery, vehicles, and so on, that is, movable and immovable property (with the exception of land plots). Leasing companies are commercial organizations that perform the functions of lessors. The contract must be concluded exclusively in writing. Upon receipt of the property for temporary use and possession, the lessee is obliged to perform maintenance and repair of the leased property at its own expense. In some cases, the leased property must be subject to state registration. As a rule, this is real estate (buildings, factories, etc.). The property that is the subject of leasing can be insured. The parties acting as the policyholder and beneficiary, as well as the period of insurance of this property, are determined by the lease agreement. The legislative regulation of leasing in modern foreign countries is of considerable interest. So, in the UK, rental operations have existed for a long time. The very first published law fixing the main provisions on lease-sale was issued in 1938, which was subsequently edited in 1954 and $1964[15]$.

Therefore, the characteristic features of the modern model of leasing as a type of financial lease can be considered as follows: first, in addition to the lessor and the lessee (respectively, the lessor and the lessee), the seller of the property, which is the owner of this property, also acts as the obligated person. The seller of the property does not act as a party to the lease agreement; secondly, the lessor (respectively, the lessor) is not the owner of the property; thirdly, the lessee (lessee) plays a major role in the lease obligation. He chooses the seller and a property, which wants to lease; fourth, another distinctive feature of the lease in respect of the lease is that the civil code in a discretionary form establishes the position that the transfer of the leased property under the lease agreement shall seller of the property, not the landlord. In other lease agreements, as a rule, the lessor transfers the property to the lessee.

It should be noted that in today's conditions, the rather difficult economic situation observed both in the world and within the Russian state-legal system, however, the situation is observed to increase activity of economic entities, especially those engaged in agricultural production. On the one hand, this is due to the increasing threats of pandlemia and, as a result, the self-ization of national agricultural markets. On the other hand, it is possible to state the reverse trend, which directly depends on the gradual exit of Russia from the crisis situation.

Ingeneral, you can trace the trends in leasing activity over the last period, which are displayed in the table (Figure. 1).

In terms of legal regulation, Federal Law "On Financial Lease (Leasing)" somewhat differently defines the concept of the contract and the signs of leasing. This Federal Law defines 3 types of leasing agreements: financial leasing, return leasing and operational leasing. In our opinion, the legal structure of the lease agreement is quite complex, it has various legal aspects. The complex subject structure, the presence of an accompanying contract for the purchase and sale of leasing property, makes this contract one of the most complex civil law contracts. A special place in this agreement is occupied by its participants (the lessor, the lessee and the seller of the property). The lessors are leasing companies established by industry or production criteria. In the agricultural sector, the largest leasing company is Rosagroleasing. 


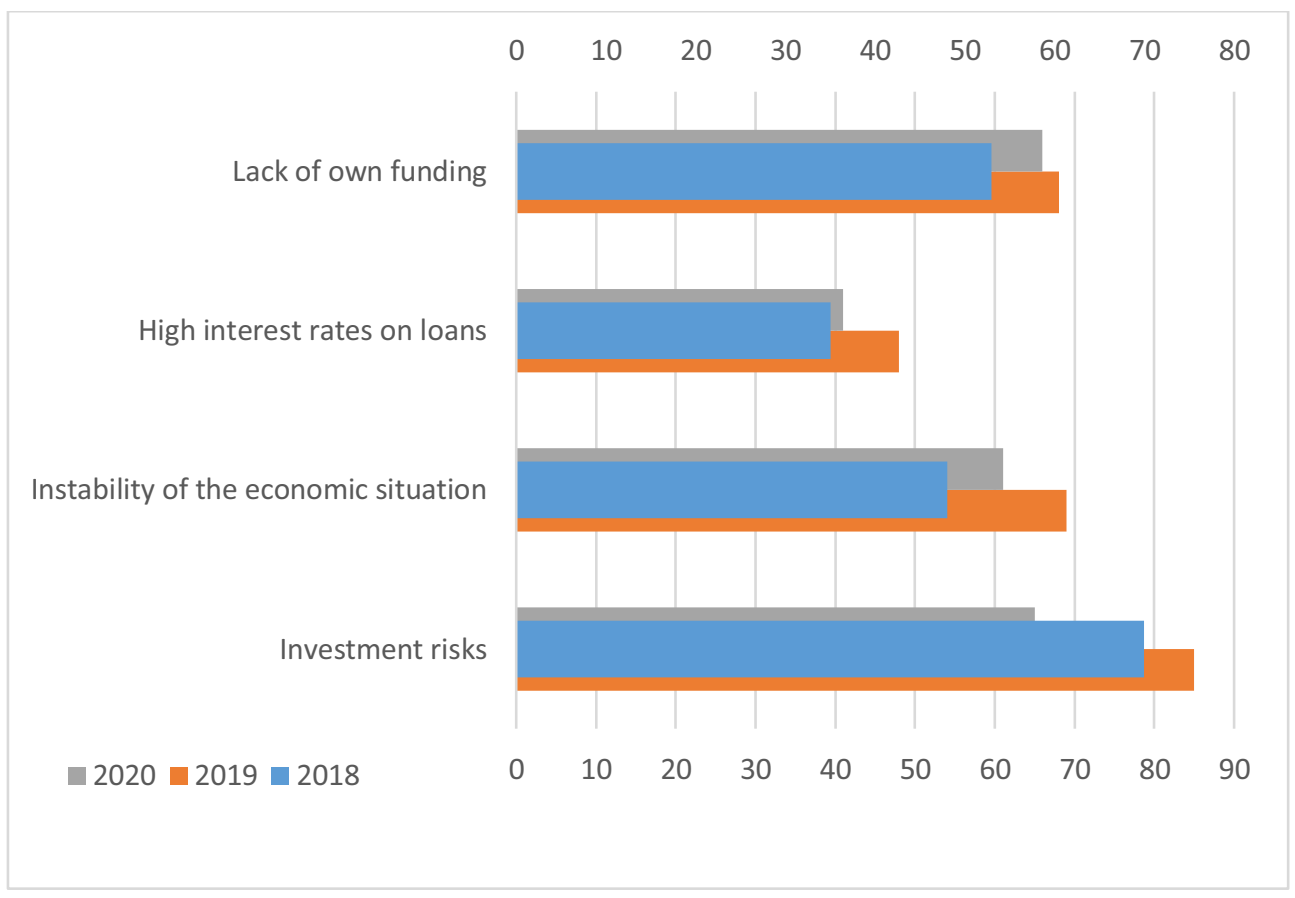

Fig.1. Factors holding back investment activity in leasing activities (as a percentage of leasing deals.

\section{Conclusion}

In general, it should be noted that leasing is beneficial for large companies that have good monetary assets. Since most of the risks associated with the implementation of the lease agreement are financial risks. Therefore, small companies or individuals do not resort to the use of leasing, since they do not have large reserves of monetary assets. At any time, the funds may run out or they may not be enough to repay the next month in the payment schedule, and then there is a risk of termination of the lease agreement unilaterally by the lessor. Of course, such small companies or individuals. individuals can try to contact the lessor with a request to extend the maturity of the payment schedule, but not any leasing company will do this. It seems that it is necessary to legally oblige the lessor to allow a later date for the repayment of the payment schedule by the lessee. Then leasing will be popular among individuals. individuals and small companies. Practice shows that most often in the lease agreement, the lessee is more responsible, since most of the responsibilities fall on him. The lessor is also liable, but its amount is significantly less than that of the lessee. The most common liability is civil law, which consists in violation of contractual obligations. A lease agreement is a type of lease agreement, but not just a lease (property lease), but a financial lease with the involvement of investment funds. The lease agreement is concluded exclusively between the lessor and the lessee, which indicates its bilateral nature. Thus, in the modern contractual form of lease (leasing) is traditionally characterized as: a) business (investment) agreement; b) bilateral (the lessee, the lessee acts in the role of landlord the lessor); c) mutual (both parties have rights and obligations); d) consensual (considered concluded from the moment of its signing by the parties); finally, the 
contract. Currently, leasing is the most profitable way to coordinate the interests of producers and consumers, leasing companies and banks. Leasing is more profitable for the purchase of expensive equipment than renting or regular purchase. Therefore, we can assume that the number of leasing transactions will only grow, and eventually the total volume of leasing investments in Russia will reach the level of developed countries, which will eventually lead to the renewal of the technical base of enterprises, and as a result, to a significant economic growth of our state.

\section{References}

1. A.Meidan, Strategic problems in international leasing, Management International Review, 24(4), 36-47 (2016)

2. T. R. Kisel, The economic essence of leasing, Science - education, production, economics: Proceedings of the International Scientific and Technical Conference. Minsk: UP "Technoprint", 2, 56 (2013)

3. G. Sharma, An assignment on features and working of leasing industry of Germany (National Law University, Joghpur, 2012)

4. Belarusian leasing: 2016 review. Official website of leasing in the Republic of Belarus. https://leasing-belarus.by/wpcontent/uploads/2015/10/belorusskij-rynok-lizinga.-obzor2016- g.pdf. Accessed June 28, 2018.

5. A. Ovchinnikov, S. Rybak, M. Alekseeva, et al., Revista Dilemas Contemporáneos: Educación, Política y Valore.

http://www.dilemascontemporaneoseducacionpoliticayvalores.com/ Año: VII Número: 1 Artículo no.:126 Período: 1 de septiembre al 31 de diciembre, 2019.

6. G. Sharma, An assignment on features and working of leasing industry of Germany, (National Law University, Joghpur, 2012)

7. J. Van Horne, J. Wachowicz, Pearson Education, 13, 760 (2019)

8. T. Beck, A. Demirguc-Kunt, Journal of Banking and Finance, 30, 2931-2943 (2006)

9. A.Eisfeldt, A.Rampini, Review of Financial Studies, 22, 1621-1657 (2019)

10. T. Beck, A. Demirguc-Kunt, Journal of Banking and Finance, 30, 2931-2943 (2006)

11. T. R Kisel, The economic essence of leasing, Science - education, production, economics: Proceedings of the International Scientific and Technical Conference. Minsk: UP "Technoprint", 2, 130 (2013)

12. The volume and dynamics of the leasing market. Official portal of RA Expert Kazakhstan. http://raexpert.kz/researches/leasing_2015/part0/. Accessed June 28, 2018.

13. V.Yan, Journal of Financial and Quantitative Analysis, 41, 709-731 (2016)

14. V.Gazman, Economic Journal of Higher School of Economics, 17(1), 130-151 (2013)

15. C.Tsang, C. Leung, Asset Finance \& Leasing in China and Hong Kong (PwC, 2014) 